\title{
KARAKTERISTIK IMPERATIF DAN REKOMENDATIF PUTUSAN-PUTUSAN KOMISI PENGAWAS PERSAINGAN USAHA
}

\author{
Dyah Hapsari Prananingrum, Tri Budiyono, dan Arie Siswanto \\ Staf Pengajar Fakultas Hukum \\ Universitas Kristen Satya Wacana \\ Korespondensi: dyah.prananingrum@yahoo.com
}

\begin{abstract}
Abstrak
Sebagai otoritas persaingan usaha, KPPU memiliki kewenangan memeriksa dan memutus perkara pelanggaran Undang-Undang Persaingan Usaha. Di samping memutus perkara, KPPU juga memiliki tugas memberikan saran/rekomendasi demi perbaikan iklim persaingan usaha. Dalam praktiknya, ada kalanya rekomendasi juga dimuat dalam putusan KPPU yang berkenaan dengan dugaan pelanggaran Undang-Undang Persaingan Usaha. Dengan demikian putusan KPPU bisa mengandung muatan imperatif maupun rekomendatif. Penelitian ini dimaksudkan untuk mengkaji muatan imperatif dan rekomendatif dalam putusan-putusan KPPU. Penelitian ini mengungkapkan bahwa kedua sifat konten putusan KPPU memang diperlukan dalam penegakan hukum yang bersifat komprehensif dan tidak semata-mata menggunakan pendekatan represif. Mengingat sensitivitas dunia usaha terhadap regulasi, konten rekomendatif menjadi salah satu wahana yang juga tepat untuk mendorong ketaatan (compliance) pihak-pihak terkait.
\end{abstract}

Kata-kata Kunci: Persaingan Usaha; Putusan KPPU; Rekomendasi KPPU.

\begin{abstract}
As a business competition organ, the Commission has the authority to examine and decide cases involving violations of Competition Law. Furthermore, the Commission also has the task of providing advice/recommendation for the government and businesses to improve the business competition climate. In practice, there are occassions when the recommendation is also contained in the Commission's decision with regard to alleged violations of the Business Competition Law. Thus the decision of the Commission may contain imperative verdict well as recommendation. This study aimed to assess the imperatives and recommendation content in the Commission's decisions. It was revealed that both content is required in a comprehensive law enforcement which was not simply based on repressive approach. Given the sensitivity of the business with regulations, the recommendations contained in the Commission's decision may be used as an appropriate vehicle to encourage adherence (compliance) to Competition Law by related parties.
\end{abstract}

Key Words: Business Competition; KPPU Decisions; KPPU Recommendation. 


\section{PENDAHULUAN}

Kehadiran UU No. 5 Tahun 1999 tentang Larangan Praktik Monopoli dan Persaingan Usaha Tidak Sehat menjadi penanda lahirnya rezim ekonomi baru, yang berbeda dengan masa-masa sebelumnya. Undang-undang ini menjadi jembatan yang menjamin persaingan dilakukan dalam koridor norma atau kaidah yang telah ditetapkan. ${ }^{1}$

Bertitik tolak pada tujuan diundangkannya UU No. 5 tahun 1999, pada Pasal 3 dapat disimpulkan bahwa tujuan dari pemberlakuan UU No. 5 tahun 1999 adalah untuk:

1. Menjaga kepentingan umum dan meningkatkan efisiensi ekonomi nasional sebagai salah satu upaya untuk meningkatkan kesejahteraan rakyat;

2. Mewujudkan iklim usaha yang kondusif melalui pengaturan persaingan usaha yang sama bagi pelaku usaha besar, pelaku usaha menengah, dan pelaku usaha kecil;

3. Mencegah praktik monopoli dan/ atau persaingan usaha tidak sehat yang ditimbulkan oleh pelaku usaha; dan

4. Menciptakan efektivitas dan efisiensi dalam kegiatan usaha.

Dalam kondisi yang demikian, negara mengintervensi dinamika kehidupan ekonomi yang sejatinya berada di ranah privat, dengan tujuan agar tercipta fairness. Kerangka intervensi negara dilakukan antara lain dengan cara:

1. (Lebih memilih) membatasi perilaku atau praktik yang bersifat monopoli dan anti-persaingan di pasar, sehingga struktur pasar menjadi lebih baik.

2. Membatasi perilaku penyalahgunaan (abusive conducts) yang dilakukan oleh perusahaan, terutama perusahaan-perusahaan yang memiliki posisi dominan.

3. Membatasi dan mengurangi hambatan untuk masuk ke dalam pasar.

Bertitik tolak dari pemikiran tersebut, secara singkat dapat dikatakan bahwa tujuan dari pemberlakuan UU No. 5 Tahun 1999 adalah agar dunia usaha dapat tumbuh serta berkembang secara sehat dan benar, sehingga tercipta iklim persaingan usaha yang sehat, serta terhindarkannya pemusatan kekuatan ekonomi pada perorangan atau kelompok tertentu, khususnya dalam bentuk praktek monopoli yang merugikan masyarakat dan bertentangan dengan cita-cita keadilan sosial.

Dalam Pasal 1 angka 1 UU No. 5 tahun 1999, konsep monopoli diberi makna luas, yaitu "penguasaan atas produksi dan atau pemasaran barang dan atau atas penggunaan jasa tertentu oleh satu pelaku usaha atau satu kelompok pelaku usaha”. Bertitik tolak dari konstruksi konsep tersebut, monopoli sejatinya mencakup 5 (lima) aksi korporasi, yaitu monopoli, monopsoni, oligopoli, oligopsoni, dan penguasaan pasar. Sementara itu, praktik monopoli diartikan sebagai "pemusat-

\footnotetext{
$\overline{1}$ Ahmad Kaylani, (ed.), Negara dan Pasar Dalam Bingkai Kebijakan dan Pasar (KPPU 2011)
} 
an kekuatan ekonomi oleh satu atau lebih pelaku usaha yang mengakibatkan dikuasainya produksi dan atau pemasaran atas barang dan atau jasa tertentu sehingga menimbulkan persaingan usaha tidak sehat dan dapat merugikan kepentingan umum."

Monopoli adalah penguasaan atas produksi dan/atau pemasaran barang atau jasa oleh satu pelaku usaha. Dalam hal ini, pelaku usaha bertindak sebagai penyedia (baca: penjual) barang atau jasa tersebut. Pasal 17 UU No. 5 Tahun 1999 sebagai dasar pengkaidahan monopoli mengatur sebagai berikut: Pelaku usaha dilarang melakukan penguasaan atas produksi dan atau pemasaran barang dan atau jasa yang dapat mengakibatkan terjadinya praktik monopoli dan atau persaingan usaha tidak sehat. Pelaku usaha patut diduga atau dianggap melakukan penguasaan atas produksi dan atau pemasaran barang dan atau jasa sebagaimana dimaksud dalam ayat (1) apabila:

a. barang dan atau jasa yang bersangkutan belum ada substitusinya; atau

b. mengakibatkan pelaku usaha lain tidak dapat masuk ke dalam persaingan usaha barang dan atau jasa yang sama; atau

c. satu pelaku usaha atau satu kelompok pelaku usaha menguasai lebih dari 50\% (lima puluh persen) pangsa pasar satu jenis barang atau jasa tertentu.
Legal structure dalam sistem hukum persaingan usaha, berdasarkan UU No. 5 Tahun 1999 dipumpunkan pada Komisi Pengawas Persaingan Usaha (KPPU). KPPU telah banyak membuat keputusan sebagai bentuk pelaksanaan tugas untuk menjaga dan menciptakan persaingan sehat. Putusan KPPU, walaupun seringkali memunculkan kontradiksi dan di-challenge melalui jalur pengadilan, harus diakui telah mampu mendorong terciptanya iklim persaingan sehat dan anti monopoli di Indonesia. Banyak putusan KPPU yang secara langsung memangkas praktik monopoli yang secara nyata terjadi dalam ranah kehidupan ekonomi. Sebagai sebuah mekanisme untuk menegakkan norma, putusan KPPU akan memiliki dampak korektif, dalam arti bahwa putusan tersebut pada dasarnya memuat koreksi terhadap praktik-praktik monopoli dan persaingan usaha tidak sehat yang dilakukan oleh pelaku usaha yang diperiksa oleh KPPU. Meski demikian, putusan KPPU akan memiliki makna hanya ketika putusan tersebut menyatakan secara tegas norma-norma hukum persaingan usaha yang harus ditaati oleh pelaku usaha.

Seperti halnya hukum pada umumnya (dalam pengertian lex atau lege), UU No. 5 Tahun 1999 hanya akan memiliki makna terhadap perilaku dan kehidupan berekonomi ketika pengaturannya bermuara pada pengabdian terhadap

$2 \quad$ Pasal 1 Angka 2 UU No. 5 tahun 1999 tentang Larangan Praktek Monopoli dan Persaingan Tidak Sehat. 
kepentingan masyarakat (public interest) dan efisiensi ekonomi (economic efficiency). Pumpunan untuk menghidupkan hukum persaingan ini ada di tangan KPPU yang pembentukannya didasarkan pada Keputusan Presiden (Keppres) No. 75 tahun 1999, sebagai pelaksanaan amanat dari Pasal 34 UU No. 5 tahun 1999. Sekalipun KPPU menjadi institusi utama yang memiliki kewenangan untuk melakukan penegakan terhadap undang-undang persaingan usaha di Indonesia, harus tetap dipahami bahwa KPPU dikoneksikan dengan lembaga peradilan yang telah terlembaga terlebih dahulu, yaitu $\mathrm{Pe}-$ ngadilan Negeri (PN) dan Mahkamah Agung (MA). Menurut Budi L. Kagramanto sebagaimana termuat dalam Jurnal Ilmu Hukum Yustisia (2007), KPPU merupakan lembaga negara komplementer (state auxiliary organ) ${ }^{3}$.

Berdasarkan Pasal 35-36 UU No. 5 Tahun 1999, dapat diinventarisir bahwa ada 7 (tujuh) tugas KPPU dan 12 (dua belas) kewenangan KPPU. Di antara tugas dan wewenang KPPU ini, melakukan penelitian dan penyelidikan, serta memutuskan apakah pelaku usaha melanggar UU No. 5 tahun 1999 atau tidak, merupakan implementasi fungsi utama dalam rangka (mengarahkan) membentuk struktur pasar persaingan yang sehat. Dari perspektif ini, Putusan KPPU menjadi instrumen untuk menciptakan keadilan (corrective justice) terhadap monopoli yang secara empiris terjadi. Hal yang menarik atas sistem yang diterapkan dalam KPPU dalam memutus suatu perkara adalah rekomendasi atau tindakan ikutan yang secara terintegrasi dimasukkan dalam putusan KPPU. Rekomendasi diberikan kepada pemerintah berdasarkan perkara-perkara persaingan usaha yang ditangani KPPU, sebagai implementasi dari tugas dan wewenang yang secara normatif terumus dalam Pasal 35-36 UU No. 5 Tahun 1999. Demikian juga halnya apabila putusan KPPU tersebut mengamanatkan tindakan lanjutan, misalnya pembentukan tim monitor untuk mengawasi pelaksanaan putusan KPPU. Dengan demikian karakteristik putusan KPPU secara signifikan akan berdampak terhadap kualitas pengaruh kondisi ekonomi dan kebijakan ekonomi Indonesia.

Oleh karena itu, menjadi relevan untuk mengkaji bagaimana putusanputusan KPPU yang berisi penegasan norma-norma hukum persaingan usaha itu mempengaruhi dinamika persaingan usaha di antara para pelaku usaha. Berkaitan dengan hal tersebut, menarik untuk mengamati bahwa dari sisi strukturnya putusan-putusan KPPU tidak seragam, khususnya ketika dihubungkan dengan keberadaan rekomendasi di dalam putusan KPPU. Ada putusanputusan KPPU yang memuat rekomendasi di dalam amar putusan, sementara itu ada pula putusan-putusan KPPU yang diletakkan di luar amar putusan. Demikian pula, ada putusan yang berisi rekomendasi yang bersifat umum,

3 Jimly Asshiddiqie, 'Memperkenalkan Gagasan Konstitusi Ekonomi' (Universitas Trisakti, Jakarta, 12 Juli 2012). 
tetapi ada pula putusan yang memuat rekomendasi yang spesifik.

Dari sudut pandang hukum, letak rekomendasi dalam putusan KPPU tentu bisa berkonsekuensi pada kekuatan mengikat dari rekomendasi tersebut. Ketika sebuah rekomendasi dimuat di bawah heading amar putusan, dapat ditafsirkan bahwa rekomendasi itu memiliki kekuatan mengikat yang lebih kuat daripada rekomendasi yang terletak di luar amar putusan. Demikian pula, rekomendasi yang bersifat umum bisa jadi akan lebih sulit untuk dilaksanakan dibandingkan dengan rekomendasi yang spesifik. Halhal yang berkaitan dengan keberadaan rekomendasi di dalam putusan-putusan KPPU itulah yang perlu dikaji lebih lanjut.

Berdasarkan uraian di atas, penelitian ini akan diarahkan untuk menjawab rumusan-rumusan masalah penelitian sebagai berikut: "Bagaimana karakteristik putusan-putusan KPPU sebagai upaya untuk mewujudkan iklim persaingan usaha yang sehat di Indonesia?" Rumusan masalah ini dimaksudkan untuk menyoroti karakteristik atribut-atribut internal putusan KPPU, khususnya struktur putusan dan posisi rekomendasi di dalam putusan-putusan KPPU.

\section{METODE PENELITIAN}

Sesuai dengan masalah yang hendak dikaji, penelitian ini dikategorikan sebagai penelitian hukum normatif, yakni penelitian yang mengedepankan studi terhadap norma-norma hukum. Penelitian normatif dimaksudkan untuk menggambarkan karakteristik putusan KPPU dalam hal praktik monopoli dengan luaran dapat diperoleh gambaran tentang profil putusan KPPU sejak KPPU berdiri dan menjalankan fungsinya sampai dengan saat ini, terutama difokuskan pada fungsi rekomendasi yang dilakukan melalui putusan terhadap perkara-perkara in concreto. Untuk kepentingan ini, maka pendekatan yang digunakan adalah pendekatan perundang-undangan (statute approach), pendekatan kasus dan pendekatan konsep (conceptual approach). Pendekatan perundang-undangan digunakan untuk meneliti peraturan perundangan yang berkaitan dengan persaingan usaha dan kebijakan di bidang ekonomi ${ }^{4}$. Tidak berhenti pada peraturan perundang-undangan saja, selanjutnya dilakukan pula analisis terhadap penerapan peraturan perundangan tersebut dalam putusanputusan hukum, khususnya putusan KPPU.

Pendekatan kasus juga digunakan dalam penelitian ini untuk melihat putusan-putusan KPPU dalam berbagai kasus untuk melihat dan menjelaskan tentang bagaimana rekomendasi KPPU diakomodasikan dalam putusanputusan KPPU. Di samping itu, pendekatan konsep digunakan untuk memahami konsep-konsep yang terdapat dalam persaingan usaha ataupun

4 Johny Ibrahim, Hukum Persaingan Usaha: Filosofi, Teori dan Implikasi di Indonesia (Bayu Media 2006) 310 . 
konsep-konsep lain yang terkait dengan permasalahan yang diangkat. Penelitian ini bersifat deskriptif-analitis, yaitu mendeskripsikan dan menganalisis karakteristik putusan KPPU dalam perkara praktik monopoli seraya menganalisis posisi dan kekuatan mengikat rekomendasi di dalam putusan-putusan KPPU.

\section{PEMBAHASAN}

\section{Kerangka Teoretik}

Sebagai suatu institusi hukum dalam persaingan usaha, KPPU memiliki kewenangan untuk menjaga efektifitas keberlakuan Undang-undang Persaingan Usaha guna menciptakan persaingan usaha yang sehat dan meniadakan monopoli di Indonesia. Pelanggaran terhadap Undang-undang Persaingan Usaha oleh pelaku usaha akan memunculkan sanksi yang dijatuhkan oleh KPPU.

Berbicara tentang efektivitas hukum, Soerjono Soekanto ${ }^{5}$ berpendapat bahwa salah satu fungsi hukum baik sebagai kaidah maupun sebagai sikap tindak atau perilaku teratur adalah membimbing perilaku manusia. Masalah pengaruh hukum tidak hanya terbatas pada timbulnya ketaatan atau kepatuhan pada hukum tapi mencakup efek total dari hukum terhadap sikap tindak atau perilaku baik yang bersifat positif maupun negatif. Adapun ketaatan seseorang bersikap tindak atau berperilaku sesuai dengan harapan pemben- tuk undang-undang bahwa pengaruh hukum terhadap sikap tindak atau perilaku, dapat diklasifikasikan sebagai ketaatan (compliance), ketidaktaatan atau penyimpangan (deviance) dan pengelakan (evasion). Konsep-konsep ketaatan, ketidaktaatan atau penyimpangan dan pengelakan sebenarnya berkaitan dengan hukum yang berisikan larangan atau perintah. Sanksi merupakan aktualisasi dari norma hukum threats dan promises, yaitu suatu ancaman tidak akan mendapatkan legitimasi bila tidak ada faedahnya untuk dipatuhi atau ditaati. Suatu sanksi dapat diaktualisasikan kepada masyarakat atau kelompok masyarakat tertentu bahkan individu dalam bentuk ketaatan (compliance), dengan kondisi tersebut menunjukkan adanya indikator bahwa hukum tersebut adalah efektif.

Keterkaitan konsep pengaruh hukum dengan konsep tujuan hukum, adalah dalam hal konsep pengaruh berarti sikap tindak atau perilaku yang dikaitkan dengan suatu kaidah hukum dalam kenyataan. Pengaruh positif atau efektifitasnya akan sangat tergantung pada tujuan atau maksud suatu kaidah hukum. Suatu tujuan hukum tidak selalu identik dinyatakan dalam suatu aturan dan belum tentu menjadi alasan yang sesungguhnya dari pembuat aturan tersebut. Tentang sanksi sebagai aktivitas hukum, Soerjono Soekanto ${ }^{6}$ mengemukakan bahwa 
"kalangan hukum lazimnya kurang memperhatikan masalah sanksi positif. Sanksi negatif lebih banyak dipergunakan karena adanya anggapan kuat bahwa hukuman lebih efektif. Dapatlah dikatakan bahwa sanksi-sanksi tersebut tidak mempunyai efek yang bersifat universal. Efek suatu sanksi merupakan masalah empiris, oleh karena itu manusia mempunyai persepsi yang tidak sama mengenai sanksi-sanksi tersebut."

Dalam sanksi negatif, yang terpenting adalah kepastiannya bila dibandingkan dengan kemanfaatan maupun keadilan. Pentingnya kepastian tersebut antara lain mengakibatkan bahwa pengawasan terhadap pelaksanaan ketentuan-ketentuan tersebut harus dilakukan secara ketat dan konsisten. Pada sanksi negatif ini, suatu ancaman hukuman benar-benar efektif atau tidak hanya untuk mencegah terjadinya kejahatan.

Penjatuhan sanksi kepada pelaku usaha yang melakukan praktik persaingan usaha tidak sehat dan monopoli pada dasarnya memiliki tujuan tertentu. Secara teoritik, menurut Herbert L. Packer ${ }^{7}$, terdapat dua pandangan konseptual tentang tujuan penjatuhan sanksi kepada rechtperson. Masingmasing pandangan akan mempunyai implikasi moral yang berbeda satu dengan yang lain, yaitu pandangan retributif (retributive view) dan pandangan utilitarian (utilitarian view). Pandangan retributif mengandaikan penjatuhan sanksi sebagai ganjaran negatif terhadap perilaku menyimpang yang dilakukan oleh warga masyarakat sehingga pandangan ini melihat sanksi hanya sebagai pembalasan terhadap kesalahan yang dilakukan atas dasar tanggungjawab moralnya masingmasing. Pandangan utilitarian melihat pemberian sanksi dari segi kemanfaatan atau kegunaannya, sehingga dalam pemberian sanksi yang dilihat adalah situasi atau keadaan yang ingin dihasilkan dengan dijatuhkannya sanksi tersebut kepada pelaku pelanggaran hukum. Sanksi diberikan dengan maksud untuk memperbaiki sikap atau tingkah laku pelanggaran terhadap hukum dan juga untuk mencegah rechtperson yang lain dari kemungkinan melakukan perbuatan yang serupa (forward-looking dan deterence) (Packer, 1968:10). Demikian pula sanksi yang dijatuhkan oleh KPPU dalam hal terjadinya pelanggaran hukum oleh pelaku usaha, maka sanksi haruslah dipahami dalam kerangka teori tentang sanksi di atas.

Pada aspek pembentukan hukum, hukum yang dibentuk sangat dipengaruhi oleh tradisi hukumnya (legal tradition). Pada negara-negara yang menganut common law tradition, pumpunan utama pembentukan hukum ada pada hakim ketika memutuskan perkara/kasus konkrit yang diperhadapkan kepadanya. Judge made law menjadi doktrin yang utama, diikuti dengan pemberlakuan doktrin stare decisis atau precedent yang mengakibatkan putusan hakim menjadi arus utama pembentukan hukum.

$7 \quad$ Herbert L. Packer, The Limits of the Criminal Sanction (Stanford University Press 1968) 9. 
Hal yang sedikit berbeda dengan apa yang telah dikemukakan pada bagian terdahulu ada pada negaranegara yang menganut tradisi civil law. Pada negara-negara civil law, pumpunan pembentukan hukum yang utama ada pada legislator. Legislator merumuskan norma/kaidah yang kemudian diterapkan oleh hakim untuk memutuskan perkara-perkara yang diperhadapkan kepadanya. Dalam bentuknya yang paling konvensional, hakim menjadi "corong undang-undang" (la bouche de la loi). Namun demikian, ujaran kuno tersebut telah banyak ditinggalkan, sebab hakim sejatinya bukan hanya sekedar corong undangundang saja tetapi memiliki peran yang jauh lebih luas dari itu, yaitu bagaimana undang-undang sebagai law in the book dioperasikan sebagai law in action. Bagaimana "menghidupkan hukum" ini sejatinya lebih sebagai artyang melibatkan segala seluruh eksistensi hakim sebagai manusia dengan human dignitynya ketimbang proses mekanistik yang miskin dengan sentuhan humanistiknya.

Namun demikian, di atas perbedaan tersebut, pada kedua tradisi hukum tersebut tersirat pengakuan bahwa hakim sejatinya memiliki posisi strategis dalam berhukum. Putusan hakim memiliki dampak yang strategis dalam kehidupan bermasyarakat. Berbagai penelitian dilakukan untuk mengkaji (bagaimana) dampak strategis putusan hakim terhadap bidang kehidupan tertentu. Skelton ${ }^{8}$ dalam pengantar seminar dengan judul "An Introduction to Impact Litigation for Children's Right", mengutip pandangan Geary P. yang mengatakan:

a strategic litigation, sometimes called impact litigation, involves selecting and bringing cases to the court with a goal of creating broader changes in society. People who bring strategic litigation want to use the law to leave a lasting mark beyond just winning the matter at hand. This means that strategic litigation cases are as much concerned with the effects that they will have on larger populations and governments as they are with the end result of the cases themselves.

Sedang Siri Gloppen ${ }^{9}$ dari Christian Michelsen Institute dalam papernya (2005) berjudul Public Interest Litigation, Social Right and Social Policy, menyatakan

...but the real policy impact is rare without organizations and social movements that can utilize the litigation process as part of a broader strategy of social and political mobilization. Litigation on its own has limited potential to change the situation on the ground, but creates opportunities for other actors. With a respective apparatus in place litigation seem to be effective in bringing out facts that can be used for advocacy purposes, fed into social and political discourses and directly inform policy processes.

Kedua pemikir tersebut sejatinya memberi tekanan bahwa putusan hakim tidak hanya berpengaruh terhadap penyelesaian kasus empirik itu sendiri, tetapi dapat menjadi pintu masuk untuk mendiskursuskan bahkan melahirkan kebijakan yang dapat memberikan impactyang lebih luas bagi

\footnotetext{
$8 \quad<$ http://dgmt.co.za/the-centre-for-child-law-on-strategic-impact-litigation/> diakses 31 Maret 2014.

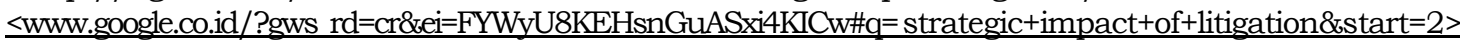
diakses 31 Maret 2014.
} 
kehidupan masyarakat. ${ }^{10}$ Dampak litigasi menggambarkan strategi untuk memilih dan menggunakan hukum sebagai instrumen untuk mewujudkan dampak akhir yang lebih luas, melampaui kasus khusus yang terkait dengan itu, baik terhadap kebijakan publik maupun pada legislasi.

Berdasarkan pandangan Gloppen tersebut, impak dampak terhadap perubahan masyarakat dapat digambarkan melalui 2 (dua) cara, yaitu melalui proses peradilan dan melalui mobilisasi sosial. Namun demikian, kedua cara tersebut dapat pula berjalan beriringan, dalam arti, antara proses peradilan dan mobilisasi sosial bersinergi menciptakan perubahan sosial.

Salah satu aspek penting yang menjadi simpul penghubung di antara proses peradilan dengan mobilisasi sosial adalah putusan pengadilan yang merupakan hasil dari sebuah proses peradilan. Untuk bisa membawa dampak sosial, putusan pengadilan harus diartikulasikan secara tepat dalam formulasi yang jelas dan tidak memunculkan ambiguitas.

Penelitian ini sejatinya mengkaji impak karakteristik putusan KPPU terhadap yang dipahami sebagai instrumen untuk mewujudkan kondisi persaingan usaha yang sehat melalui koridor. Jika pandangan Gloppen tersebut dihadapmukakan dengan penelitian ini, sejatinya memiliki kesejajaran yaitu mengkaji dampak putusan (dalam hal ini adalah putusan KPPU yang dalam bentuk sanksi) terhadap perubahan sosial (dalam hal ini adalah kebijakan ekonomi).

\section{Profil Putusan KPPU}

KPPU adalah sebuah lembaga independen yang dibentuk untuk memenuhi amanat UU No. 5 Tahun 1999 tentang Larangan Praktik Monopoli dan Persaingan Tidak Sehat. KPPU dalam melaksanakan tugas dan wewenangnya memerlukan arah pandang yang jelas, sehingga apa yang menjadi tujuannya dapat dirumuskan dengan jelas dan pencapaiannya dapat direncanakan dengan tepat dan terinci. Arah pandangan tersebut terumus dalam visi dan misi KPPU.

Putusan KPPU merupakan (salah

Tabel 1

Jumlah Putusan KPPU

berdasarkan Tahun 2001 - 2013

\begin{tabular}{ccc}
\hline NO. & TAHUN & JUMLAH \\
\hline 1. & 2001 & 2 \\
2. & 2002 & 2 \\
3. & 2003 & 4 \\
4. & 2004 & 5 \\
5. & 2005 & 9 \\
6. & 2006 & 5 \\
7. & 2007 & 4 \\
8. & 2008 & 7 \\
9. & 2009 & 5 \\
10. & 2010 & 3 \\
11. & 2011 & 2 \\
12. & 2012 & 1 \\
13 & 2013 & 1 \\
\hline
\end{tabular}

Sumber: Data Sekunder

\footnotetext{
10 Dalam konteks ini, meskipun yang dikaji adalah putusan-putusan KPPU yang pada hakikatnya bukan merupakan lembaga pengadilan, pandangan Gloppen dipandang relevan karena sama seperti putusan pengadilan, putusan KPPU juga memuat amar yang harus dilaksanakan.
} 
Dari limapuluh 50 putusan tersebut, sebanyak 39 (78\%) merupakan putusan atas pemeriksaan dugaan pelanggaran hukum persaingan usaha yang didasarkan pada laporan pihak-pihak di luar KPPU, sedangkan 11 (22\%) merupakan putusan atas pemeriksaan yang didasar-kan pada inisiatif KPPU sendiri.

\section{Penanganan Perkara atas Dasar Laporan dan Inisiatif}

Berdasarkan kewenangan KPPU sebagaimana diatur dalam Pasal 36 UU No. 5 tahun 1999, perkara yang ditangani oleh KPPU, dapat dikelompokkan menjadi 2 (dua), yaitu atas dasar laporan, dan atas dasar inisiatif dari KPPU. ${ }^{11}$ Perkara berdasarkan laporan adalah pemeriksaan yang dilakukan perkara yang diperiksa oleh KPPU karena adanya laporan yang disampaikan oleh masyarakat maupun dari pelaku usaha yang dirugikan. Sedangkan perkara inisiatif adalah perkara yang ditangani oleh KPPU berdasarkan hasil monitoring/pengamatan dan penelitian KPPU terhadap situasi dan kondisi yang diduga menimbulkan (iklim) persaingan yang tidak sehat. ${ }^{12}$ Tujuan dilaku- kannya penelitian maupun pengawasan terhadap sektor-sektor tersebut adalah untuk memetakan struktur usaha dan pola perilaku yang muncul dalam persaingan di antara pelaku usaha.

Berdasarkan Peraturan KPPU No. 1 tahun 2006 tentang Tata Cara Penanganan Perkara di KPPU, setelah ada laporan atau inisiatif maka KPPU akan membentuk Komisi. Pemeriksaan Komisi - secara garis besar - dilakukan dengan urutan acara sebagai berikut:

a. Pemeriksaan Pendahuluan, ${ }^{13}$

b. Pemeriksaan Lanjutan, ${ }^{14}$

c. Putusan Komisi,

d. Eksekusi Putusan KPPU.

Dari 50 (lima puluh) putusan KPPU yang diteliti, sebaran kedua kategori putusan berdasarkan laporan atau inisiatif, dapat dikemukakan melalui tabel 2.

Dari tabel 2, dapat digambarkan bahwa $78 \%$ dari perkara yang terkait dengan monopoli sebagai objek penelitian ini berasal dari laporan masyarakat/pelaku usaha. Sementara 22\% perkara yang ditangani oleh KPPU berasal dari pengembangan penelitian atas dugaan adanya kegiatan usaha

Pasal 36 huruf (c) UU No. 5 tahun 1999

12 Peraturan Komisi No.1 tahun 2010 telah mengatur 2 (dua) kegiatan monitoring pelaku usaha yaitu (i) Penelitian, yang bertujuan untuk mendapatkan bukti awal dugaan pelanggaran oleh pelaku usaha dalam rangka perkara inisiatif, dan (ii) Pengawasan, yang bertujuan mengawasi perilaku pelaku usaha dominan dalam rangka pencegahan. Seiring dengan hal ini, Peraturan Komisi Nomor 4 Tahun 2010 mengatur bahwa kegiatan monitoring dilaksanakan oleh Bagian Monitoring dan Pengawasan yang fokus pada pengawasan, sedangkan Bagian perkara inisiatif lebih fokus pada kegiatan penelitian.

13 Berdasarkan Pasal 4 ayat (1) Peraturan KPPU No. 1 tahun 2006, Tim Pemeriksa Pendahuluan mempunyai tugas mendapatkan pengakuan Terlapor berkaitan dengan dugaan pelanggaran yang dituduhkan dan/atau mendapatkan bukti awal yang cukup mengenai dugaan pelanggaran yang dilakukan oleh Terlapor serta merekomendasikan kepada Komisi untuk menetapkan perlu atau tidaknya dilakukan Pemeriksaan Lanjutan;

14 Berdasarkan Pasal 5 ayat (1) Peraturan KPPU No. 1 tahun 2006, Tim Pemeriksa Lanjutan mempunyai tugas menemukan bukti ada atau tidak adanya pelanggaran dan menyerahkan hasil Pemeriksaan Lanjutan ke Komisi untuk dinilai oleh Majelis Komisi; 
dan atau tindakan pelaku usaha yang dapat mengakibatkan terjadinya praktik monopoli dan atau persaingan usaha tidak sehat, sesuai dengan tugas dan wewenang KPPU sebagaimana dimaksud

\section{Tabel 2}

Putusan KPPU Tahun $2001-2013$ berdasarkan Laporan/Inisiatif Pemeriksaan

\begin{tabular}{crccc}
\hline NO & TAHUN & LAPORAN & INISIATIF & JUMLAH \\
\hline 1 & 2001 & 2 & 0 & 2 \\
2 & 2002 & 1 & 1 & 2 \\
3 & 2003 & 2 & 2 & 4 \\
4 & 2004 & 4 & 1 & 5 \\
5 & 2005 & 7 & 2 & 9 \\
6 & 2006 & 5 & 0 & 5 \\
7 & 2007 & 3 & 1 & 4 \\
8 & 2008 & 7 & 0 & 7 \\
9 & 2009 & 4 & 1 & 5 \\
10 & 2010 & 3 & 0 & 3 \\
11 & 2011 & 1 & 1 & 2 \\
12 & 2012 & 0 & 1 & 1 \\
13 & 2013 & 0 & 1 & 1 \\
\hline & & $\mathbf{3 9}$ & $\mathbf{1 1}$ & $\mathbf{5 0}$ \\
\hline
\end{tabular}

dalam Pasal 36 Undang-undang No. 5 Tahun 1999.

Selain itu, perbedaan yang cukup signifikan terkait dengan karakteristik laporan dan inisiatif dapat dipahami sebagai kewajaran. Sebab, Indonesia memiliki wilayah yang sangat luas sementara KPPU merupakan institusi yang (masih hanya) ada di ibu kota negara. Jangkauan untuk melakukan pengamatan dan pengawasan terhadap persaingan usaha di Indonesia tidak pelak lagi terkendala oleh keterbatasan jumlah personil dan dana. Sehingga, hanya perkara-perkara yang menonjol dan menjadi perhatian publik saja yang mendapat perhatian secara khusus dari KPPU. Apabila dicermati dari kasus yang penangannya berdasarkan inisiatif KPPU, dapat disimpulkan bahwa perkara ini adalah perkara yang memiliki nilai perkara yang besar dan/atau perkara yang strategis sehingga akan berpengaruh terhadap iklim persaingan usaha di Indonesia. Sementara besarnya persentase perkara yang termasuk kategori laporan sejatinya merupakan indikasi besarnya perhatian dan tingginya tingkat kepekaan pelaku usaha terhadap berbagai persoalan yang berpotensi mendistorsi iklim persaingan usaha yang sehat di Indonesia.

\section{Jenis Pelanggaran yang Diduga Dilanggar Dilakukan}

Secara keseluruhan, putusan KPPU yang dijadikan objek penelitian ini memuat 163 item tentang dugaan pelanggaran atas Undang-Undang No. 5

\section{Tabel 3}

Sebaran Pasal-pasal dalam UndangUndang Persaingan Usaha dalam dalam putusan KPPU Tahun 2001 - 2013

\begin{tabular}{|c|c|c|c|c|}
\hline NO & PASAL & JML & KATEGORI & $\%$ \\
\hline 1 & $19-21$ & 69 & Penguasaan Pasar & $42 \%$ \\
\hline 2 & 25 & 18 & Posisi Dominan & $11 \%$ \\
\hline 3 & 17 & 16 & Monopoli & $10 \%$ \\
\hline 4 & 15 & 14 & Perjanjian Tertutup & $9 \%$ \\
\hline 5 & 22 & 14 & Persekongkolan & $9 \%$ \\
\hline 6 & $5-8$ & 9 & Penetapan Harga & $6 \%$ \\
\hline 7 & 4 & 5 & Oligopoli & $3 \%$ \\
\hline 8 & 11 & 4 & Kartel & $2 \%$ \\
\hline 9 & 14 & 2 & Integrasi Vertikal & $1 \%$ \\
\hline 10 & 26 & 2 & Jabatan Rangkap & $1 \%$ \\
\hline 11 & 9 & 2 & Pembagian wilayah & $1 \%$ \\
\hline 12 & 27 & 2 & Pemilikan Saham & $1 \%$ \\
\hline 13 & 28 & 2 & Pengambilalihan & $1 \%$ \\
\hline 14 & 16 & 2 & $\begin{array}{l}\text { Perjanjian dengan } \\
\text { pihak luar negeri }\end{array}$ & $1 \%$ \\
\hline 15 & 18 & 1 & Monopsoni & $1 \%$ \\
\hline \multirow[t]{2}{*}{16} & 13 & 1 & Oligopsoni & $1 \%$ \\
\hline & TOTAL & 163 & & $100 \%$ \\
\hline
\end{tabular}


Tahun 1999 tentang Larangan Praktik Monopoli dan Persaingan Usaha Tidak Sehat (Undang-Undang Persaingan Usaha), yang sebarannya dapat dilihat dalam tabel 3.

Dari tabel 3 tersebut kategori pelanggaran Undang-Undang Persaingan Usaha Undang-Undang No. 5 Tahun 1999 yang paling dominan dalam putusan-putusan yang diteliti adalah Penguasaan Pasar yang diatur dalam Pasal 19-21 (69 item, 42\%), disusul oleh Posisi Dominan (18 item, 11\%), Monopoli (16 item, 10\%), Perjanjian Tertutup dan Persekongkolan (masingmasing 14 item, 9\%) dan Penetapan Harga (9 item, 6\%). Oligopoli berada pada posisi ketujuh dengan jumlah 5 item (3\%) dan diikuti oleh Kartel (4 item, $2 \%)$. Sementara itu, kategori yang lain masing-masing hanya berjumlah $1 \%$.

Di antara kategori-kategori di atas, ada beberapa kategori yang berdasarkan Undang-undang No. 5 Tahun 1999 Undang-Undang Persaingan Usaha dapat dipecah lagi ke dalam sub-sub kategori, yaitu Penguasaan Pasar (Pasal 19-21), Posisi Dominan (Pasal 25), dan Perjanjian Tertutup (Pasal 15).

a. Penguasaan Pasar

Untuk kategori Penguasaan Pasar (Pasal 19-21), secara lebih rinci dapat dikemukakan bahwa subkategori yang paling dominan adalah tindakan Diskriminasi (35 item, 21\%), tindakan Menolak/Menghalangi Pelaku Usaha (21 item, 13\%), disusul oleh tindakan Menghalangi Konsumen Pesaing (8 item, 5\%), membatasi Peredaran Barang \& Jasa (4 item,
2\%) dan Predatory Pricing (1 item, 1\%).

b. Posisi Dominan

Kategori Posisi Dominan (Pasal 25) dapat dipecah menjadi 3 subkategori, yaitu tindakan Membuat Trade Conditions yang Menghalangi Konsumen (6 item, 4\%), Membatasi Pasar \& Menghambat Teknologi (1 item, 1\%), dan Menghambat Calon Pesaing (5 item, 3\%). Di dalam putusan ada sebanyak 6 item (4\%) dugaan pelanggaran Posisi Dominan yang tidak secara eksplisit menunjuk pada sub-kategori tertentu.

c. Perjanjian Tertutup

Kategori Perjanjian Tertutup dapat dipecah menjadi 3 sub kategori, yaitu Conditional Exclusive Dealing (4 item, 3\%), Exclusive Supply / NonSupply (3 item, 2\%), dan Tying-in (6 item, 4\%). Untuk kategori ini ada 1 item (1\%) dugaan pelanggaran yang tidak secara spesifik menyebut subkategori.

\section{Kategori Putusan Berdasarkan Isi}

Dari sisi isi putusannya, putusanputusan KPPU yang dijadikan obyek penelitian ini dapat pilah menjadi 3 kategori, yaitu putusan bahwa Terlapor terbukti melakukan pelanggaran (Putusan Terbukti), putusan bahwa Terlapor tidak terbukti melakukan pelanggaran (Putusan Tidak Terbukti) dan putusan bahwa Terlapor (atau sebagian Terlapor, dalam hal Terlapor lebih dari 1) terbukti melanggar sebagian pasal tertentu yang dijadikan dasar pemeriksaan dan tidak terbukti melang- 
Tabel 4

Putusan KPPU Tahun 2001 - 2013 Berdasarkan Isi

\begin{tabular}{rccccc}
\hline NO & TAHUN & TERBUKTI & $\begin{array}{c}\text { TIDAK } \\
\text { TERBUKTI }\end{array}$ & $\begin{array}{c}\text { TERBUKTI } \\
\text { SEBAGIAN }\end{array}$ & JML \\
\hline 1 & 2001 & 0 & 2 & 0 & 2 \\
2 & 2002 & 0 & 1 & 1 & 2 \\
3 & 2003 & 1 & 0 & 3 & 4 \\
4 & 2004 & 0 & 0 & 5 & 5 \\
5 & 2005 & 1 & 0 & 8 & 9 \\
6 & 2006 & 1 & 1 & 3 & 5 \\
7 & 2007 & 0 & 1 & 3 & 4 \\
8 & 2008 & 1 & 2 & 4 & 7 \\
9 & 2009 & 0 & 0 & 5 & 5 \\
10 & 2010 & 1 & 1 & 1 & 3 \\
11 & 2011 & 0 & 2 & 0 & 2 \\
12 & 2012 & 0 & 0 & 1 & 1 \\
13 & 2013 & 1 & 0 & 0 & 1 \\
\hline \multicolumn{7}{r}{} & 6 & 10 & 34 & 50 \\
\hline
\end{tabular}

gar pasal yang lain (Putusan Terbukti

Sebagian). Sebaran untuk ketiga kategori tersebut ditampilkan dalam tabel 4.

Apabila dikaitkan dengan kategori Laporan/Inisiatif, sebaran putusan KPPU berdasarkan isinya dapat dikemukakan sebagai berikut:

Tabel 5

Isi Putusan KPPU berdasarkan Kategori Laporan/Inisiatif

\begin{tabular}{llcccc}
\hline NO & \multirow{2}{*}{ KATEGORI } & TERBUKTI & $\begin{array}{r}\text { T ID A K } \\
\text { TERBUKTI }\end{array}$ & $\begin{array}{c}\text { TERBUKTI } \\
\text { SEBAGIAN }\end{array}$ & JML \\
\hline 1 & LAPORAN & 4 & 7 & 28 & 39 \\
2 & INISIATIF & 2 & 3 & 6 & 11 \\
\hline & & & & JML & $\mathbf{5 0}$ \\
\hline
\end{tabular}

Dari segi amar putusan, terdapat 13 kategori amar putusan di luar amar putusan yang sekedar menyatakan apakah Terlapor terbukti atau tidak terbukti melakukan pelanggaran Undang-Undang Persaingan Usaha. Ketiga belas kategori tersebut meliputi:

a) Amar putusan yang memerintahkan pelaku usaha untuk melakukan sesuatu;

b) Amar putusan yang memerintahkan pelaku usaha untuk membayar denda; c) Amar putusan yang melarang pelaku usaha untuk melakukan sesuatu;

d) Amar putusan yang menyatakan suatu kondisi (termasuk kesepakatan) batal demi hukum;

e) Amar putusan yang membatalkan perjanjian/kesepakatan tertentu;

f) Amar putusan yang menetapkan pembatalan suatu kondisi (termasuk kesepakatan);

g) Amar putusan yang meminta pelaku usaha untuk melakukan sesuatu;

h) Amar putusan yang menghukum denda;

i) Amar putusan yang menghukum non-denda;

j) Amar putusan yang menyarankan pemerintah (pusat) untuk melakukan sesuatu;

k) Amar putusan yang menyarankan pemerintah daerah untuk melakukan sesuatu;

1) Amar putusan yang menyarankan pelaku usaha untuk melakukan sesuatu; dan

m)Amar putusan yang menyarankan KPPU untuk melakukan sesuatu. 
Kategori amar putusan yang terbanyak di dalam putusan-putusan KPPU adalah kategori (h), yaitu amar putusan yang menghukum denda. Kategori ini mencapai jumlah 61 (33\%). Kategori (a), yaitu amar putusan yang memerintahkan pelaku usaha untuk melakukan sesuatu, berada pada urutan kedua dengan jumlah 58 (32\%), kategori (j), yaitu amar putusan yang menyarankan pemerintah (pusat) untuk melakukan sesuatu berada di peringkat ketiga dengan jumlah 23 (13\%), dan kategori $(\mathrm{m})$, yaitu amar putusan yang menyarankan KPPU untuk melakukan sesuatu, menempati urutan berikutnya dengan jumlah 15 (8\%). Kategori amar yang paling sedikit ditemukan adalah (d), yaitu amar putusan yang menyatakan suatu kondisi (termasuk kesepakatan) batal demi hukum, yang hanya berjumlah $1(1 \%)$.

Rekomendasi merupakan hal yang bersifat khusus dari putusan yang diberikan oleh Komisi terhadap kasus konkrit yang diajukan kepada KPPU. Dalam melaksanakan tugas dan wewenang, KPPU sebagai lembaga publikc memiliki tanggung jawab untuk menegakkan hukum persaingan usaha, serta memberikan saran dan pertimbangan kepada pemerintah. Selain itu, KPPU juga berkewajiban untuk memberikan informasi mengenai isu-isu persaingan usaha kepada stakeholders, termasuk di dalamnya sosialisasi tentang putusan-putusan yang dikeluarkan KPPU. ${ }^{15}$

Rekomendasi yang diberikan Komisi sebagai pemutus perkara persaingan usaha, dapat diformulasikan secara tegas maupun dapat dirumuskan secara samar-samar. Jika dirumuskan secara tegas, dalam putusannya, Komisi meletakkan sebagai bagian yang dari putusan dengan anak judul "rekomendasi", ataupun istilah lain yang memiliki makna serupa. Misalnya, dalam perkara KPPU No. 01/ KPPU-I/2002 rekomendasi yang diberikan oleh KPPU dinyatakan sebagai berikut:

1. Menyarankan kepada pemerintah untuk membuat kebijakan yang pada pokoknya dapat menghilangkan hambatan bagi seluruh peserta pelelangan/tender pengadaan pipa casing dan tubing guna mendapatkan Supporting Letter untuk fasilitas jasa heat treatment dan atau upsetting dari pelaku usaha yang memiliki kemampuan dan fasilitas heat treatment dan atau upsetting di dalam negeri;

2. Meminta kepada pelaku usaha yang memiliki kemampuan dan fasilitas heat treatment dan atau upsetting dalam hal ini PT. Seamless Pipe Indonesia Jaya (Terlapor I) dan PT. Citra Tubindo Tbk. (Terlapor II) untuk tidak menggunakan posisi dominannya dengan cara melakukan diskriminasi dan atau menghambat pemberian Supporting Letter untuk fasilitas jasa heat treatment dan atau upsetting bagi pelaku usaha yang membutuhkannya;

3. Meminta kepada pelaku usaha dalam hal ini PT. Seamless Pipe Indonesia Jaya (Terlapor I) dan PT Citra Tubindo (Terlapor II) untuk melakukan kegiatan usaha secara adil, jujur, dan terbuka dalam menetap-

15 Komisi Pengawas Persaingan Usaha, Buku Penjelasan Katalog Putusan KPPU Periode 2000 September 2009 (KPPU 2009). 
kan harga jasa heat treatment dan atau upsetting bagi pelaku usaha yang membutuhkannya;

4. Menyarankan kepada pemerintah untuk mengembangkan mekanisme kontrol terhadap kewajaran harga pelelangan/tender dengan metode Harga Perkiraan Sendiri (HPS)/ Owner Estimate (OE)/Engineering Estimate (EE) untuk menjamin terciptanya persaingan usaha yang sehat dan efisien.

Selain itu, rekomendasi juga dikonstatasi sebagai bagian dari amar putusan. Dalam Putusan KPPU No. 07/ KPPU-L-I/2001, dalam amar putusannya menyatakan sebagai berikut:

"Menyarankan kepada Gubernur Jawa Timur sebagai atasan langsung Kepala Dinas Peternakan Jawa Timur, dan Ketua Panitia Lelang untuk mengambil tindakan administrative sehubungan dengan keterlibatan keduanya dalam pelanggaran Pasal 22 UUUndangUndang No. 5/1999 yang secara sah dan meyakinkan dilakukan oleh terlapor. "

Berdasarkan rekomendasi yang diberikan oleh Komisi kepada Pemerintah, dari 50 Putusan KPPU yang menjadi objek penelitian terdapat 10 (sepuluh) atau 20\% (dua puluh per seratus) putusan yang memberi rekomendasi kepada pemerintah.

\section{Pengaruh Konten Sanksi Putusan KPPU Terhadap Pelaku Usaha Yang Melakukan Praktik Monopoli Dalam Konteks Penegakan Hukum Persaingan Usaha}

Dalam ilmu hukum disebutkan bahwa hukum bermuatan sanksi, yang akan dikenakan kepada setiap pihak yang melanggar hukum. Sanksi negatif haruslah dapat menimbulkan efek jera (deterrent effect) bagi para pelaku pelanggaran hukum, maupun bagi setiap orang agar tidak melakukan pelanggaran hukum. Sanksi yang memiliki karakteristik yang demikian terutama adalah sanksi pidana, baik pidana penjara (kurungan) maupun denda.

Namun dalam realita hukum, penjatuhan sanksi ataupun tujuan adanya sanksi dalam suatu ketentuan perundang-undangan tidak dapat tercapai manakala pelaku tetap melakukan pelanggaran hukum. Dengan demikian tidak selamanya ada korelasi antara sanksi dengan kepatuhan pelaku pelanggaran yang dalam konteks kajian ini adalah pelaku usaha.

KPPU sebagai lembaga yang memiliki tugas dan kewenangan untuk melaksanakan penegakan hukum UU Persaingan Usaha. Lebih lanjut lembaga ini memberikan saran pertimbangan kepada Pemerintah terkait dengan kebijakan yang dianggap berpotensi menciptakan praktik monopoli dan persaingan usaha tidak sehat. Saat ini KPPU telah menjalin hubungan dengan berbagai instansi terkait yang merupakan regulator sektor, yakni dalam kerangka harmonisasi kebijakan. Harmonisasi adalah sebuah langkah yang paling efektif, untuk menginternalisasi nilai-nilai persaingan ke dalam kebijakan pemerintah. Pemahaman yang baik dari pemerintah sebagai regulator sektor akan menjadi jalan bagi terimplementasinya kebijakan persaingan. Dalam perspektif kebijakan persaingan, patut dipahami 
bahwa tugas KPPU terbatas hanya pada persaingan semata, sebaliknya regulator sektor memiliki peran yang sangat besar termasuk untuk menyatakan sebuah sektor terbuka atau tertutup bagi persaingan (keluar masuk pelaku usaha baru).

Tantangan besar dihadapi KPPU, karena sering disalahpahami bahwa KPPU cenderung menjadi penghalang program Pemerintah dalam mengatur sebuah sektor. Padahal persaingan dan kebijakan Pemerintah memiliki tujuan akhir yang sama yakni kesejahteraan masyarakat. Dalam kondisi tertentu, distorsi terhadap mekanisme pasar atau persaingan bisa saja terjadi karena pertimbangan tertentu. Namun demikian tujuan akhirnya haruslah kesejahteraan masyarakat, bukan keuntungan sekelompok pelaku usaha tertentu saja.

Tantangan harmonisasi kebijakan ke depan sangat besar, mengingat semakin banyaknya sektor yang mengubah model pengelolaannya dari monopoli menuju persaingan. Bersamaan dengan bekerjanya KPPU Periode kedua, lahir beberapa Undang-Undang yang mengatur perubahan pengelolaan tersebut. Misalnya UU di perkeretaapian, kepelabuhanan, kebandarudaraan, pengelolaan terminal bus juga di sektor ketenagalistrikan. Tetapi sayangnya, dalam perkembangan beberapa sektor misalnya kepelabuhanan dan kebandarudaraan keterlibatan pelaku usaha swasta bukannya mendorong perbaikan, tapi malah menciptakan kondisi pelayanan yang semakin buruk dan tarif yang meningkat. Bahkan muncul kesan, keterbukaan sektor seperti hanya memindahkan hak monopoli dari Negara kepada swasta.

KPPU melihat bahwa kondisi ini disebabkan oleh implementasi yang tidak tepat. Sektor yang awalnya natural monopoly, dan tidak memiliki alternatif pengganti tidak dapat dilepaskan kepada mekanisme pasar secara penuh. Untuk itu, keterlibatan regulator diperlukan mengingat di dalamnya terdapat keterbatasan lahan yang menyebabkan persaingan cenderung terbatas.

Hal seperti inilah yang akan menjadi tantangan berat bagi KPPU guna mendorong regulator mengambil perannya dalam porsi yang optimal sehingga pengelolaan sektor dengan mendorong swasta di dalamnya dapat menciptakan sektor yang efisien dan bermuara pada terciptanya kesejahteraan masyarakat.

Hal lain yang patut diperhatikan adalah terkait tugas pemberian saran pertimbangan, di mana saran pertimbangan Periode Penguatan Perekonomian Melalui Persaingan Usaha Komisi Pengawas Persaingan Usaha - Republik Indonesia tersebut tidak mengikat Pemerintah atau regulator sektor. Tidak ada konsekuensi apapun bagi Pemerintah bila tidak melaksanakan saran KPPU. Pemerintah atau regulator sektor, dengan pertimbangan politisnya dapat mengabaikan saran KPPU apabila berpandangan bahwa saran tersebut tidak tepat, sekalipun dalam perspektif persaingan dapat mendorong tercipta- 
nya efisiensi dan efektifitas pengelolaan sektor.

Kondisi ini menjadi tantangan KPPU. KPPU harus mampu membuktikan kepada publik bahwa setiap saran yang diberikan adalah sebuah pilihan yang harus diambil Pemerintah apabila menginginkan pengelolaan sektor menjadi lebih baik. Setiap saran pertimbangan yang diajukan harus memiliki landasan yang kuat melalui background paper yang dapat menjelaskan nilai strategis sebuah saran, sehingga Pemerintah menyadari pentingnya implementasi saran yang mendorong terciptanya pengelolaan sektor yang efisien dan bermuara pada kesejahteraan masyarakat. Untuk mendorong persaingan yang sehat antar pelaku usaha, sepanjang tahun anggaran 2012 KPPU telah menyampaikan juga 9 (sembilan) saran dan pertimbangan terhadap pemerintah. Saran dimaksud adalah:

1. Saran dan Pertimbangan KPPU terkait Tender Pekerjaan Pembangunan Pelabuhan Laut Samboja Kabupaten Kutai Kartanegara Provinsi Kalimantan Timur Tahun Anggaran 2009;

2. Saran dan Pertimbangan KPPU terkait Tender Pekerjaan Pembangunan Pelabuhan Laut Samboja Kabupaten Kutai Kartanegara Provinsi Kalimantan Timur Tahun Anggaran 2009;

3. Saran dan Pertimbangan terkait Tender Pekerjaan Pembangunan Pelabuhan Laut Samboja, Pembangunan Pelabuhan Terpadu di
Kecamatan Kota Bangun Pada Paket Pekerjaan Pendamping Kegiatan Pembangunan Pelabuhan Terpadu Dinas Perhubungan Kabupaten Kutai Kartanegara Provinsi Kalimantan Timur Tahun Anggaran 2009;

4. Saran dan Pertimbangan Terkait Jasa Penyediaan Tenaga Listrik untuk Pelanggan Bisnis (B-3) dan Industri (I-2, I-3, dan I-4) selama periode bulan Januari 2010 hingga Juni 2010 di Wilayah Jawa dan Bali;

5. Saran dan Pertimbangan KPPU terkait Kebijakan Penyelenggaraan Asuransi TKI kepada - Ketua Komisi VI DPR RI cc. Ketua Komisi IX DPR RI, Presiden RI,Menteri Tenaga Kerja dan Transmigrasi RI;

6. Saran dan Pertimbangan KPPU terkait Pengadaan Bahan Makanan untuk Tahanan dan Narapidana di Lembaga Pemasyarakatan Kelas II A Pekanbaru kepada - Menteri Hukum dan Hak Asasi Manusia RI;

7. Koordinasi dengan stakeholders taksi di Batam pada tanggal 17 September 2012 mengenai praktik monopoli pengusahaan taksi di Bandara Hang Nadim, Batam yang dihadiri oleh Dinas Perhubungan Kota Batam, Otorita Bandara Hang Nadim, BP Batam, Akademisi dari Universitas Internasional Batam serta pelaku usaha taksi Batam, seperti Taksi Barelang dan Silver $\mathrm{Cab}$;

8. Koordinasi dengan Kementerian UMKM mengenai penyusunan Rancangan Peraturan Pemerintah tentang Undang-Undang Kemitraan; 
9. Surat saran terkait kegiatan EKP Rumput laut, KPD KPPU Manado. Periode Penguatan Perekonomian Melalui Persaingan Usaha Komisi Pengawas Persaingan Usaha Republik Indonesia

Dari keseluruhan saran yang telah disampaikan KPPU tersebut, 78\% mendapat respon positif dari Pemerintah yang berupa, (1) membuat kebijakan sesuai saran (2) menunda pelaksanaan kebijakan dan (3) mencabut kebijakan yang menurut KPPU tidak sesuai dengan prinsip persaingan usaha yang sehat berdasarkan UU Persaingan Usaha.

Pengaruh sanksi terhadap kebijakan persaingan usaha maupun persaingan usaha itu sendiri dapat dilihat dalam beberapa kasus tersebut di bawah ini.

Pertama, Perkara Nomor: 25/ KPPU- I/2009 mengenai dugaan Pelanggaran terhadap Pasal 5 dan Pasal 21 Undang-Undang No. 5 Tahun 1999 tentang Larangan Praktik Monopoli dan Persaingan Usaha Tidak Sehat. Pada tanggal 4 Mei Tahun 2010, Komisi Pengawas Persaingan Usaha (KPPU) telah mengumumkan penetapan putusan terhadap Perkara yaitu dugaan pelanggaran terhadap Pasal 5 dan Pasal 21 UU Persaingan Usaha. Dugaan Pelanggaran tersebut terkait dengan penetapan harga fuel surcharge dalam industri jasa penerbangan domestik. Para pelaku usaha yang diduga melakukan pelanggaran dan ditetapkan sebagai terlapor adalah
PT. Garuda Indonesia (Terlapor I), PT Sriwijaya Air (Terlapor II), PT Merpati Nusantara Airlines (Terlapor III), PT Mandala Airlines (Terlapor IV), PT Riau Airlines (Terlapor V), PT Travel Express Aviation Services (Terlapor VI), PT Lion Mentari Airlines (Terlapor VII), PT Wing Abadi Airlines (Terlapor VIII), PT Metro Batavia (Terlapor IX), PT Kartika Airlines (Terlapor X), PT Linus Airways (Terlapor XI), PT Trigana Air Service (Terlapor XII), dan PT Indonesia Air Asia (Terlapor XIII).

Fuel surcharge merupakan sebuah komponen tarif baru dalam maskapai penerbangan yang ditujukan untuk menutup biaya yang diakibatkan oleh kenaikan harga avtur yang signifikan sebagai imbas dari kenaikan harga minyak dunia. Fenomena pemberlakuan fuel surcharge dalam industri penerbangan sesungguhnya lazim berlaku di beberapa belahan dunia. Namun demikian, adanya penetapan fuel surcharge oleh INACA diduga merupakan bentuk kartel oleh KPPU. Akibat dari tentangan KPPU tersebutlah maka fuel surcharge dibatalkan dan besaran fuel surcharge diserahkan sepenuhnya kepada mekanisme pasar oleh setiap maskapai penerbangan. Namun dengan dihapuskannya penetapan harga fuel surcharge dan menyerahkannya kepada mekanisme pasar, oleh INACA, ternyata tidak diikuti oleh penurunan yang signifikan ketika komponen pembentuknya ikut turun. Kondisi inilah yang menjadi dasar adanya dugaan perjanjian penetapan harga. 


\section{PENUTUP}

Berdasarkan hal-hal yang telah diuraikan di atas, dapat dikatakan bahwa pada dasarnya terdapat dua konten putusan KPPU, yakni konten yang bersifat imperatif dan konten yang berdsifat rekomendatif. Kedua sifat konten putusan KPPU memang diperlukan dalam penegakan hukum yang bersifat komprehensif dan tidak semata-mata menggunakan pendekatan represif. Mengingat sensitivitas dunia usaha terhadap regulasi, konten rekomendatif menjadi salah satu wahana yang juga tepat untuk mendorong ketaatan (compliance) pihakpihak terkait.

Meskipun demikian kedua konten tersebut masih perlu untuk dibedakan secara lebih tegas dalam struktur putusan KPPU, karena masih ditemukan keberadaan konten rekomendatif yang berada di dalam amar putusan KPPU yang semestinya bersifat imperatif. Demikian pula, konten rekomendasi KPPU juga perlu mempertimbangkan secara seksama perihal adressat rekomendasi (pihak mana yang diharapkan melaksanakan rekomendasi), spesialitas rekomendasi (hal spesifik apa yang diharapkan dilakukan oleh pihak yang diberi rekomendasi) dan juga feasibility rekomendasi (apakah rekomendasi yang diberikan dapat dilakukan oleh pihak yang diberi rekomendasi).

\section{DAFTAR BACAAN}

\section{Buku}

Ibrahim, Johnny, Hukum Persaingan Usaha: Filosofi, Teori, dan Implikasi di Indonesia (Bayu Media 2006).

Packer, Herbert L., The Limits of the Criminal Sanction (Stanford University Press 1968).

Kaylani, Ahmad (editor), Negara dan Pasar Dalam Bingkai Kebijakan dan Pasar (KPPU 2011).

Komisi Pengawas Persaingan Usaha, Buku Penjelasan Katalog Putusan KPPU Periode 2000 - September 2009 (KPPU 2009).

Soekanto, Soerjono, Perspektif Teoritis

Studi Hukum dalam Masyarakat (Rajawali Press 1985).

\section{Makalah Seminar}

Asshiddiqie, Jimly, 'Memperkenalkan Gagasan Konstitusi Ekonomi' (Universitas Trisakti, Jakarta, 12 Juli 2012). 
